\title{
Use of Internet Resources for the Formation of Creative and Communicative-Creative Competence of Students
}

\author{
Novoselov S.A.* Ivanov P.A. \\ Ural State Pedagogical University, Yekaterinburg, Russian Federation \\ *Corresponding author. Email: inobr@list.ru
}

\begin{abstract}
The article considers the problem of preparing students for participating in international creative projects. For this purpose, it is proposed to use computer support to form their creative competence and communicative-creative competence, including using Internet resources. The general and particular tasks of the application of computer support for this activity are determined. The Internet resource CreaWise CIC is described, which was developed specifically for the formation of the competencies considered in the article based on the use of technology of activating individual and group creativity - associative-synectic technology (AC technology). A number of key aspects of computer support are described that provide a sufficient level of effectiveness in organizing the activities for the formation of communicative and creative competence of students and the organization of international interaction in the framework of their project activities. Examples of computer support implemented and tested in the framework of complex creative activities are given.Computer support of co-creation activities is capable of ensuring the formation of diverse age-group, child-adult project groups with participants speaking different languages. The use of AC technology as a unifying core of the components of activity and the creative results of children and adults activates the process of forming communicative and creative competence of all participants in the project group, regardless of age. Work experience in project groups organized on such principles is especially important for the professional development of students in pedagogical profiles of higher education.
\end{abstract}

Keywords: creative competence, communicative and creative competence, technology to enhance student

creativity, computer support of creativity, digitalization of education

\section{INTRODUCTION}

One of the problems attracting the attention of a wide circle of researchers, organizers, practitioners of education, as well as employers and governments of most developed countries in the world, is the problem of developing the creativity of the younger generation. For example, already in the White Paper of 1997 in the United Kingdom, the main directions for the development of creative education were identified. Along with raising the standards of literacy and mathematical abilities, the document urged to revise the main accents of education in anticipation of the new century and new requests, to direct efforts to unleash the creative potential of every young person, since the country's future and its economic prosperity depend on it. This document became an impetus for the creation of new documents, educational initiatives, and led to the emergence of public and government committees and organizations involved in the development of students' creative abilities.

In the context of modernization of Russian education and the transition to a competency-based education paradigm, the problem of developing the creativity of the younger generation has also acquired new aspects. According to the competence paradigm, graduates of a higher educational institution must possess not only theoretical knowledge in their professional field, but also be prepared for the practical application of knowledge in professional situations on the basis of value guidelines, moral standards and socio-cultural settings that have been formulated and passed public testing, and also a conscious motivation for professional activity, communication and behavior in the conditions of the rapid development of information and communication figures technologies and dynamically developing social Internet networks and network projects. At the same time, the development of students' creative abilities should become a component of the process of forming their professional competence. And the ability to creative activity should be formed both in the individual and personal aspect, and in the aspect of communication, the behavior of the individual in the creative group in the process of performing collective creative projects in the context of an ever-increasing digitalization of education. And, therefore, the synthesis of creative and communicative competencies is becoming 
relevant, which will ensure that graduates of higher education institutions are ready for creative work as part of creative groups and collectives using the advantages of a digital society.

The terms "creative competence" or "creative competence" are often used in scientific publications. So, in the interpretation of I. A. Zimnyaya and S. M. Kolomiyets, creative competence presupposes the presence of such abilities as: the ability to find the causes of certain phenomena; find unknown relationships of known quantities, new approaches to known problems; the ability to identify opportunities for the practical application of the laws of known disciplines in nontraditional situations; solve non-standard problems, including areas that are outwardly far from the studied field of knowledge; identify the main contradictions in the study area; set new challenges and problems.

The rapid growth of the number of innovative projects, including network projects implemented in Russia and foreign countries and requiring the involvement of specialists of different profiles, often speaking different languages, brought up in different national traditions of preparing for professional activities and, especially, for creative activities, makes necessary introduction to pedagogical terminology of a special designation of a synthetic personality neoplasm - communicative and creative competence.It should be noted that the origin of the concept of "communicative competence" is associated with the name of D. Hymes, who considered grammatical, sociolinguistic, strategic and discursive competencies as the main components of communicative competence.

It should be noted that the origin of the concept of "communicative competence" is associated with the name of D. Hymes, who considered grammatical, sociolinguistic, strategic and discursive competencies as the main components of communicative competence. The main idea of communicative competence according to D. Hymes is an internal understanding by the subject of communication of the situational relevance of the language. There is no need to justify the growing relevance of the problem of situational relevance in the aspect of fancifully developing communication processes in Internet networks

In domestic linguodidactics, this concept was developed by M. N. Vyatyutnev. He interpreted communicative competence as a willingness to choose and implement programs of speech behavior, depending on the person's ability to navigate in a particular communication environment; ability to classify situations depending on the topic, tasks and communicative attitudes in the process of mutual adaptation.

The importance of the communicative component in the process of collective creativity was emphasized by V.I. Andreev. Having identified six blocks of personality traits, the development of which will ensure a person's readiness for successful creative activity, he included in their composition a block of "communicative and creative abilities". In it, V. I. Andreev highlights: the ability to accumulate and use the creative experience of others; ability to cooperate in the process of creative activity, the ability to avoid conflicts in the process of creativity and resolve them. It is obvious that in the conditions of penetration of digital technologies into the most delicate spheres of creativity, the development of these abilities will take on new shades.

\section{RESEARCH QUESTIONS}

The development of network interaction between universities in different countries led to the idea of using Internet resources to organize students' project activities aimed at creating creative and communicative-creative competencies, however, the market for Internet resources, despite its saturation with various types of software, is not always fully able to provide computer support of these processes. The key issue is the quality, completeness, orientation, complexity and integrity of the software selected for the formation of creative and communicativecreative competencies, as well as computer support for technologies to enhance creative activity.

\section{RESEARCH TASKS}

The main objective of the study is to develop and implement a model of computer support for the formation of communicative and creative competence, the role of a key component in which will be Internet resources that ensure the effectiveness of project activities carried out in several languages. Supporting tasks serve the private aspects of the implementation of technologies for enhancing educational and creative activities and form the following groups:

- prevention of subjective barriers that arise among project participants;

- reducing the impact of objective barriers that participants in project activities have;

- correction of factors that negatively affect the effectiveness of the formation of communicative and creative competence.

\section{STATEMENT OF THE PROBLEM}

All of the above characteristics of creative competencies no longer fully correspond to the social need for the implementation of international creative projects, participation in which has become necessary and affordable for a large number of professionals. To realize this need, it is necessary to form a communicative and creative competence in the process of teaching students of the profession a special kind of readiness for effective creative activity - communicative and creative competence. This term was proposed in 2010 by E.V. Sergeeva and S.A. Novoselov. In their interpretation, communicative and creative competence is seen as the ability and readiness for effective cooperation in situations of a new kind in the process of creative activity in the 
project group in the conditions of foreign language communication. It involves the accumulation and sharing of creative experience of group members and ensures the achievement of creative results in all the main components of the creative process.

One of the ways to formulate the competencies under discussion is the use of design technology for training. Moreover, the content of a creative project should be aimed both at developing the ability to think creatively, and at achieving a creative result with the maximum possible use by each subject of the creative process of at least one or two foreign languages. For this, at the stage of preparing the project, it is necessary to apply such technologies of activating individual and group creativity that would motivate and adapt the project participants to creative activity in a foreign language, and would use the possibilities of combining and mutually enriching the cultural characteristics in which the project participants were brought up. One of such technologies in Russia is associative-synectic technology (AS technology) of activization of creative activity.

\section{RESEARCH METHODS}

When performing the study, a combination of theoretical and empirical methods was used, namely, theoretical modeling, case study and model experiment.

\section{RESULTS AND DISCUSSION}

The implementation of the main task began with an analysis of the software market, including the digital resources market, which today serves the various educational and organizational needs of students, whose volumes are growing steadily, often overtaking the process of understanding the possibilities of their use, starting from web implementations of popular office suites (in the form Office Online, Google Documents, etc.), ending with narrow web services (MyStudyLife, Twiddla, Google Academy, etc.). Therefore, for the effective organization of "remote" interaction of students in project groups to solve creative problems, a balanced approach to the choice of means is needed, with which you can ensure that the requirements for the formation of creative and communicative-creative competencies are met. A variant of such a set of tools was tested in the concept of the CreaWise CIC Internet resource created by the efforts of creative groups of the Ural State Pedagogical University (Ural State Pedagogical University) and the socially oriented enterprise CreaWise. In the process of interaction, various methods of computer support for the organization of work were tested, both between the permanent employees of this enterprise, and between the student groups of USPU and the University of York organized by them. The following computer support was proposed and experimentally tested in a closed testing process: content management systems (Fork CMS, WordPress, ImpressPages, etc.), software for organizing social interaction (hereinafter, an expression from the professional jargon of information technology specialists will be used) - "social engines Networks "(LiveStreet CMS, Oxwall, etc.), activity planning software (Group Office CRM, Feng Office CRM, Collabtive, etc.), digital software and services providing digital interaction (Google Hangouts, appear.in, Google Documents, MediaWiki and others).

The results of the analysis made it possible to determine the guidelines for the selection of computer support for the formation of the communicative and creative competence of students and the construction of a specific architecture for the interactions of project participants:

- the content of computer support should include software that provides effective synchronous and asynchronous interaction of project participants;

- used computer support should reduce the negative aspect of the influence of the following factors arising in the activities of project participants - feedback efficiency, reliability of the transmitted / received information, its relevance and continent;

- a set of software tools included in computer support should ensure at least $100 \%$ satisfaction of the needs of participants in project activities arising at various stages of the project.

To start building the architecture of interactions, it was proposed to use the engine of the social network, which became its central link. CreaWise Social Network provides a way of dialogue that is most familiar to potential members of a creative group through an Internet resource, or an Internet resource and a user.

The social network CreaWise Social Network (hereinafter referred to as the network) is conditionally closed. It is not indexed by search and other automatic (for example, spam bots) systems, however, registration in it is open to everyone who wants to realize and develop their creative abilities, improve their competence in working in international project groups.

The network is built on the open-source engine Oxwall and is modular. The modules can be used in different combinations to achieve different goals: in a few minutes you can turn the network into a site for establishing contacts of interest, or you can fully equip it for an international competition. Currently, the network uses general purpose modules: user panel, network members, groups, projects, events, forums, blogs, photos, videos, links.

The user panel is used similarly to the news feed on any network, however, it can be customized as you wish. For example, a composer who wants to keep abreast of the latest cultural news in order to draw inspiration from them can add RSS feeds to the panel, which are configured to export RSS feeds from relevant sources. You can also add blocks with arbitrary HTML content.

The module that displays network participants also processes the profile of the user himself. The CreaWise Social Network user profile is his working visiting card, his way of showing himself to the community of inventors (in the broad sense of the word), his way of expressing himself. A profile, similar to a user panel, can be 
customized. For example, a composer or inventor wants to place demo options on his profile. This desire is realized by placing the corresponding block in an arbitrary place of the page grid. On the other hand, a person engaged in photography can create a "photo greeting" and place it at the very top of his profile. In other words, the network provides tools for this.

A network would not be a network if its members were isolated from each other. To overcome it, a "Groups" module is provided in the network. This module, like all of the above, is a general purpose module. It allows you to create associations of different creative orientations and different content of creative activity: from groups of "interests" to special closed project groups. Each group receives two communication tools: "Wall" and "Forum", which act similarly to the well-known components of social networks. For example, the composer has agreed with other composers to write a joint symphony, or the inventor is looking for specialists to refine his inventive idea. On the Wall, they publish the main stages of work and their results, and at the Forum they discuss fragments of the future work, share its possible options and fragments.

The expected result of the creation of the project team is a project for the advertisement of which there is a singlename module. This module provides the necessary informative and graphic minimum for advertising each project being created, each creative result, in all types of creative activity: logo, HTML description (with an unlimited number of characters), "Wall" for feedback. Also, there is the possibility of raising funds for the implementation of the project. It should be noted that CreaWise is not a commercial organization, therefore, all projects should be socially significant and not have any commercial benefits (at least at this stage of development of this new form of creative interaction).

Also, the network provides a special module "Events", by analogy with existing social networks. For example, if one of the stages of the street landscape design project is a community work day, why not invite everyone to take part in this part of the project?

Other network modules (blogs, photos, videos, links, etc.) are official. They are integrated into the modules already considered.

Despite the fact that the CreaWise Social Network uses well-known tools of the worldwide network, it is necessary to emphasize its peculiarity once again - it is intended: a) in the pedagogical aspect - to form creative and communicatively creative competence of students of various profiles and specialties; b) in the professional and personal aspect - for the successful cooperation of creative people, no matter in what country of the world they live.

To continue the construction of the interaction architecture, it was proposed to introduce the use of a catalog of visual and poetic images, developed on the basis of the Galleria gallery management system, which has multilingual support, which helped to ensure the implementation of the stages of search and selection of visual and poetic images to implement the technology of enhancing creative activity - AC technology, developed by S. A. Novoselov ("Design of Artificial Poems"). Graphic editors with a "low learning threshold" of their functionality - Drawpile and Paint.NET — were chosen as a means of replenishing the visual images of this catalog. Also considered was the option of organizing activities under conditions of extremely little experience in using data and alternative graphic editors, which consisted of a review of analogues aimed at achieving the goals of subjects of educational and creative activities in terms of working with visual images. This review should not be exhaustive, since there are a fairly large number of known image file formats. In this regard, it is enough to mention the popular formats: JPEG, GIF, PNG. For working with visual images using a graphical editor, PNG is considered the best format due to the optimal combination of platform support and raster encoding capabilities with transparency. After choosing a graphic editor, you should focus on the main features inherent in any graphic editor: work with files (create, open, save, import, export), graphic editing tools (selection, cutting, copying, pasting, resizing), imitation graphic tools (pencil, brush, eraser, fill). After familiarizing yourself with the basic tools, you should process a randomly (or purposefully) selected image using the effects provided by the graphics editor, and also examine the possibilities of mixing layers of the graphic composition. This concludes the process of mastering the tools necessary for the implementation of the visualization phase of AC technology, organized by the project manager using the appropriate computer support.

In continuation of the description of computer support for the process of forming the communicative and creative competence of students, it is worth noting the mandatory use of software tools for joint editing of text (or close to them) documents and graphic compositions. It was suggested that Google Docs be used as an example of a cloud-based toolkit, and Etherpad as a custom toolkit for working on local and global networks. To organize a mutual discussion of graphic compositions in real time (the formation of communicative and creative competence), it was proposed to use the possibility of joint drawing of the Drawpile editor. At the same time, it is possible to organize this type of interaction both in local and global networks.

It is not worth leveling the capabilities of information and inquiry and information retrieval systems as a key component of the content of computer support for the formation of communicative and creative competence of students. Depending on the purpose of the search, preferences and compliance with the principle of redundancy of computer support, you can use the most suitable software tools: Yandex, Google, Rambler, Mail.Ru Search, Bing, Sputnik, Academic, IPS FIPS, eLibrary, Google Academy, etc. Together with this the importance of fixing search results and the contribution of these results to the overall project result is growing, which may already be provided with the previously proposed computer support.

A special place is played by the role of computer support for the co-creation activities of different age, child-adult 
project groups with participants speaking different languages. The experience of children and adults groups organized in a joint project of a socially-oriented enterprise CreaWise with Ural State Pedagogical University and the University of York showed that the use of computer support for the implementation of AC technology, as a uniting core of activity components and creative results of children and adults, activates the process of forming a communicative and creative competencies of all members of the project team, regardless of age. This is especially important in cases when students of pedagogical profiles work as part of project teams. They are activating not only the formation of creative and communicative-creative competence, but also the process of forming professional competencies of a teacher.

\section{CONCLUSION}

The process of forming communicative and creative competence of students is inextricably linked with the process of interaction of people interested in the effectiveness of their own creativity, often speaking different languages, brought up in different national cultures, traditions of preparing for professional activities, and a remote geographical location. Such "unevenness" can both impede and accompany creative interaction. The joint work of the socially-oriented enterprise CreaWise CIC with the Ural State Pedagogical University and the University of York made it possible to enrich all participants with new fruitful ideas, both in creative and in

\section{REFERENCES}

[1] Dorokhova, T.S., Galaguzova, M.A., Volgina, I.V. (2018), "Socio-pedagogical Support for Children with Special Educational Needs at Pre-school Education Institution", The European Proceedings of Social \& Behavioural Sciences: VII International Conference Early Childhood Care and Education, pp. 22-27.

[2] Hymes, D. (1972), On Communicative Competence. Sociolinguistics, Penguin, Harmondsworth, 293 p.

[3] National Advisory Committee on Creative and Cultural Education (NACCCE), (1999), All our futures: creativity, culture and education, Department for Education and Employment, London, available at: http://sirkenrobinson.com/pdf/allourfutures.pdf

[4] Verkhoturova, Ju.A., Galaguzova, Ju.N., Sergeeva, N.N. (2016), "The technique of game skills development for parents raising young children", The European Proceedings of Social \& Behavioural social aspects. I managed to find new forms of organizing project activities, to check the basic ways of organizing creative work that integrates the creativity of each member of the project group using the associativesynectic technology of creativity, to select and test the effectiveness of digital tools for organizing project activities, the process of which activates the formation of creative and communicative-creative students' competencies, as well as a set of their professional competencies. The obtained results were further developed in the new experience of researchers at the Institute of Pedagogy and Child Psychology of the Ural State Pedagogical University - in the implementation of the new network of scientific and educational project "Children's Academy of Invention", developing in close collaboration with the Department of Education of the Administration of the city of Yekaterinburg and a small innovative enterprise LLC "Institute for the Design of Innovations" ("IDN"). Teachers, employees and student volunteers of the University and IDI enterprises continue to improve the content of computer support developed in previous experience, increase its power, expand its functionality in the process of organizing the educational and creative activities of project participants: children, teachers and parents, university teachers and students. The accumulated potential of computer support for inventing children and adults will provide a higher level of organization of new international youth and creative projects of different ages in the international digital educational space.

Sciences, No 233, pp. 150-154, DOI: 10.1016/j.sbspro.2016.10.174

[5] Andreev, V.I. (1998), Dialectics of education and self-education of a creative person. Fundamentals of pedagogy of creativity, [Dialektika vospitaniya i samovospitaniya tvorcheskoj lichnosti. Osnovy pedagogiki tvorchestva], Izd-vo Kazanskogo un-ta, Kazan', 238 p.

[6] Bastrikova, E.M. (2004), Communicative competence as a linguodidactic phenomenon. Russian and comparative philology: Linguocultural aspect, [Kommunikativnaya kompetenciya kak lingvodidakticheskij fenomen. Russkaya i sopostavitel'naya filologiya: Lingvokul'turologicheskij aspekt], Izd-vo Kazanskogo un-ta, Kazan', 348 p.

[7] Zimnyaya, I.A. (2004), Key competencies as an effective and targeted basis of the competency-based approach in education, [Klyuchevye kompetentnosti kak rezul'tativno-celevaya osnova kompetentnostnogo 
subjects of the educational process", Pedagogical

podhoda v obrazovanii], Issledovatel'skij centr problem kachestva podgotovki specialistov, Moscow, 38 p.

[8] Kolomiec, S. M. (2010), Creative competencies of students of socio-economic specialties, [Tvorcheskie kompetencii studentov social'no-ekonomicheskih special'nostej], Izd-vo Pero, Moscow, 181 p.

[9] Novoselov, S.A. (2011), “Associative-synectic technology for the development of creativity of the education and science, ["Associativno-sinekticheskaya tekhnologiya razvitiya kreativnosti sub"ektov obrazovatel'nogo processa", Pedagogicheskoe obrazovanie i nauka], No 1, pp. 72-77.

[10] «Social networks in Russia» [Sotsial'nyye Seti V Rossii] (2014), Mail.RuGroup, available at: https://corp.mail.ru/media/files/issledovanie-auditorijsotcialnykh-setej.pdf

(In

Russian) 